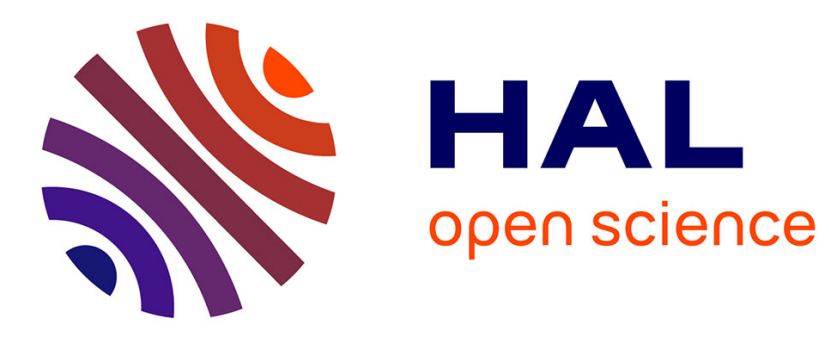

\title{
Stable 17-electron Mo(III) complexes containing alkyl ligands
}

\author{
Erwan Le Grognec, Rinaldo Poli, Li-Sheng Wang
}

\section{To cite this version:}

Erwan Le Grognec, Rinaldo Poli, Li-Sheng Wang. Stable 17-electron Mo(III) complexes containing alkyl ligands. Inorganic Chemistry Communications, 1999, 2 (3), pp.95-97. 10.1016/S13877003(99)00019-2 . hal-03304651

\section{HAL Id: hal-03304651 \\ https://hal.science/hal-03304651}

Submitted on 4 Oct 2021

HAL is a multi-disciplinary open access archive for the deposit and dissemination of scientific research documents, whether they are published or not. The documents may come from teaching and research institutions in France or abroad, or from public or private research centers.
L'archive ouverte pluridisciplinaire HAL, est destinée au dépôt et à la diffusion de documents scientifiques de niveau recherche, publiés ou non, émanant des établissements d'enseignement et de recherche français ou étrangers, des laboratoires publics ou privés. 


\section{Stable 17-electron Mo(III) complexes containing alkyl ligands}

Erwan Le Grognec, ${ }^{a}$ Rinaldo Poli ${ }^{\mathrm{a}, *}$ and Li-Sheng Wang ${ }^{\mathrm{b}}$

a Laboratoire de Synthèse et d'Electrosynthèse Organométalliques, Faculté des Sciences "Gabriel”, Université dé Bourgogne, 6 Boulevard Gabriel, 21100 Dijon, France

${ }^{b}$ Department of Chemistry and Biochemistry, University of Maryland, College Park, MD 20742, USA

Correspondence to: Prof. Rinaldo Poli

Laboratoire de Synthèse et d'Electrosynthèse Organometalliques

Faculté des Sciences "Gabriel"

6, Boulevard Gabriel

21100 Dijon (France)

tel: $+33-03.80 .39 .68 .81$

fax: $+33-03.80 .39 .60 .98$

E-MAIL: poli@u-bourgogne.fr

Keywords: Half-sandwich complexes; 17-electron compounds; Mo(III)-alkyl bonds; Alkylation reactions

\section{Abstract}

The alkylation of the half-sandwich complex $\mathrm{CpMoCl}_{2}\left(\eta^{4}\right.$-diene) (diene $\left.=\mathrm{C}_{4} \mathrm{H}_{6}, 2,3-\mathrm{Me}_{2} \mathrm{C}_{4} \mathrm{H}_{4}\right)$ affords the first thermally stable 17-electron compounds containing Mo(III)-alkyl bonds. 
Mononuclear organometallic complexes of Mo(III) are paramagnetic and quite reactive. The most previously described stable species contain metal-carbon bonds to $\pi$ ligands only. Examples include arene complexes such as $\mathrm{Mo}\left(\eta^{7}-\mathrm{dmpt}\right)\left(\eta^{1}-\mathrm{dmpt}\right)_{2}\left(\mathrm{dmpt}=\mathrm{SC}_{6} \mathrm{H}_{3}(\mathrm{Mes})_{2}-2,6\right.$; Mes $\left.=\mathrm{C}_{6} \mathrm{H}_{2} \mathrm{Me}_{3}-2,4,6\right)$ [1] cyclopentadienyl complexes such as $\left[\left(\mathrm{C}_{5} \mathrm{Ph}_{5}\right)_{2} \mathrm{Mo}\right]^{+}[2]$, and $\mathrm{CpMoCl}_{2}\left(\mathrm{PR}_{3}\right)_{2}\left(\mathrm{Cp}=\eta^{5}-\mathrm{C}_{5} \mathrm{H}_{5}\right)$ [3], diene complexes such as $\mathrm{CpMoCl}_{2}\left(\eta^{4}-\mathrm{C}_{4} \mathrm{H}_{6}\right)$ [4,5], and allyl complexes such as $\mathrm{CpMo}\left(\eta^{3}-\mathrm{C}_{3} \mathrm{H}_{5}\right)_{2}[6,7]$, and $\left[\mathrm{CpMo}\left(\eta^{3}-\mathrm{C}_{3} \mathrm{H}_{5}\right)\left(\eta^{4}-\mathrm{C}_{4} \mathrm{H}_{6}\right)\right]^{+}[5]$. Single $(\sigma)$ $\mathrm{Mo}(\mathrm{III})-\mathrm{C}$ bonds to aryl ligands are extremely rare, two examples being $\mathrm{Li}_{3} \mathrm{MoAr}_{6} \cdot 3 \mathrm{Et}_{2} \mathrm{O}(\mathrm{Ar}$ $=\mathrm{Ph}, p$-Tol) $[8,9]$. To the best of our knowledge, compounds containing a single bond to an alkyl ligand have not been previously reported, although dinuclear, diamagnetic alkylmolybdenum(III) compounds containing metal-metal bonds are known [10,11,12]. A few years ago, we attempted to produce the first such example by alkylation of $\mathrm{CpMoCl}_{2}\left(\mathrm{PR}_{3}\right)_{2}$ complexes. When $\mathrm{PR}_{3}=\mathrm{PMe}_{3}$, spectroscopic (EPR) evidence for the formation of the desired alkyl-Mo(III) product was obtained at low temperature, but a facile decomposition occurred upon warming to room temperature [13]. Trapping experiments indicated that this decomposition involves $\mathrm{Mo}(\mathrm{III})-\mathrm{CH}_{3}$ bond homolysis, the formation of $\mathrm{CH}_{4}$ and $\mathrm{CpMo}\left(\mathrm{CH}_{3}\right)\left(\mathrm{PMe}_{3}\right)_{3}$ being observed when the reaction was conducted in THF in the presence of excess $\mathrm{PMe}_{3}$. When $\mathrm{PR}_{3}=\mathrm{PMe}_{2} \mathrm{Ph}$, the same reaction led to the ortho-metallated compound $\mathrm{CpMo}\left(\mathrm{C}_{6} \mathrm{H}_{4} \mathrm{PMe}_{2}\right)\left(\mathrm{PMe}{ }_{2} \mathrm{Ph}\right)_{2}[13]$.

We now wish to report the formation and stability of mononuclear, paramagnetic alkylcontaining cyclopentadienyl-diene complexes of $\mathrm{Mo}(\mathrm{III})$. Complex $\mathrm{CpMo}\left(\mathrm{CH}_{3}\right)_{2}\left(\eta^{4}-\mathrm{C}_{4} \mathrm{H}_{6}\right), \mathbf{1}$, is obtained by low temperature alkylation of $\mathrm{CpMoCl}_{2}\left(\eta^{4}-\mathrm{C}_{4} \mathrm{H}_{6}\right)$ [5] with $\mathrm{MeMgBr}$ (see Scheme 1). The use of one equivalent of the methyl Grignard reagent allows the isolation of the mixed chloromethyl complex, $\mathrm{CpMoCl}\left(\mathrm{CH}_{3}\right)\left(\eta^{4}-\mathrm{C}_{4} \mathrm{H}_{6}\right)(\mathbf{2})^{2}$. The two complexes show EPR resonances with distinctive (in dilute solutions) hyperfine splittings caused by the syn and anti external diene $\mathrm{H}$ atoms and by the alkyl $\mathrm{H}$ atoms, whereas no discernible coupling is observed for the internal diene and $\mathrm{Cp}$ protons (Figure 1). The hyperfine coupling constants of the three types of $\mathrm{H}$ atoms for compound $\mathbf{1}$ and $\mathbf{2}$ are accidentally degenerate. This is shown by the successful simulation of the spectra as a binomial undecet (for 1) and octet (for 2) resulting from coupling to 10 or 7 , respectively, accidentally equivalent $\mathrm{H}$ nuclei. Complex $\mathrm{CpMo}\left(\mathrm{CD}_{3}\right)_{2}\left(\eta^{4}-\mathrm{C}_{4} \mathrm{H}_{6}\right)\left(\mathbf{1}-\mathrm{d}_{6}\right)$, which was synthesized from $\mathrm{CpMoCl}_{2}\left(\eta^{4}-\mathrm{C}_{4} \mathrm{H}_{6}\right)$ and $\mathrm{CD}_{3} \mathrm{MgI}$ (see footnote 1) displays a quintet resonance with $\mathrm{g}$ value and Mo and $\mathrm{H}$ hyperfine constants identical with those of $\mathbf{1}$ (Figure 1b). An analogous reaction between $\mathrm{CpMoCl}_{2}\left(\eta^{4}-\mathrm{C}_{4} \mathrm{H}_{6}\right)$ and $\mathrm{Me}_{3} \mathrm{SiCH}_{2} \mathrm{MgCl}$ (2.2 equiv) yielded $\mathrm{CpMo}\left(\mathrm{CH}_{2} \mathrm{SiMe}_{3}\right)_{2}\left(\eta^{4}-\mathrm{C}_{4} \mathrm{H}_{6}\right)$ (3), while treatment of 
$\mathrm{CpMoCl}_{2}\left(\eta^{4}-2,3-\mathrm{Me}_{2} \mathrm{C}_{4} \mathrm{H}_{4}\right)$ with $\mathrm{MeMgBr}$ (2 equiv) allowed access to the sterically more encumbered $\mathrm{CpMoMe}_{2}\left(\eta^{4}-2,3-\mathrm{Me}_{2} \mathrm{C}_{4} \mathrm{H}_{4}\right)(4)^{3}$.
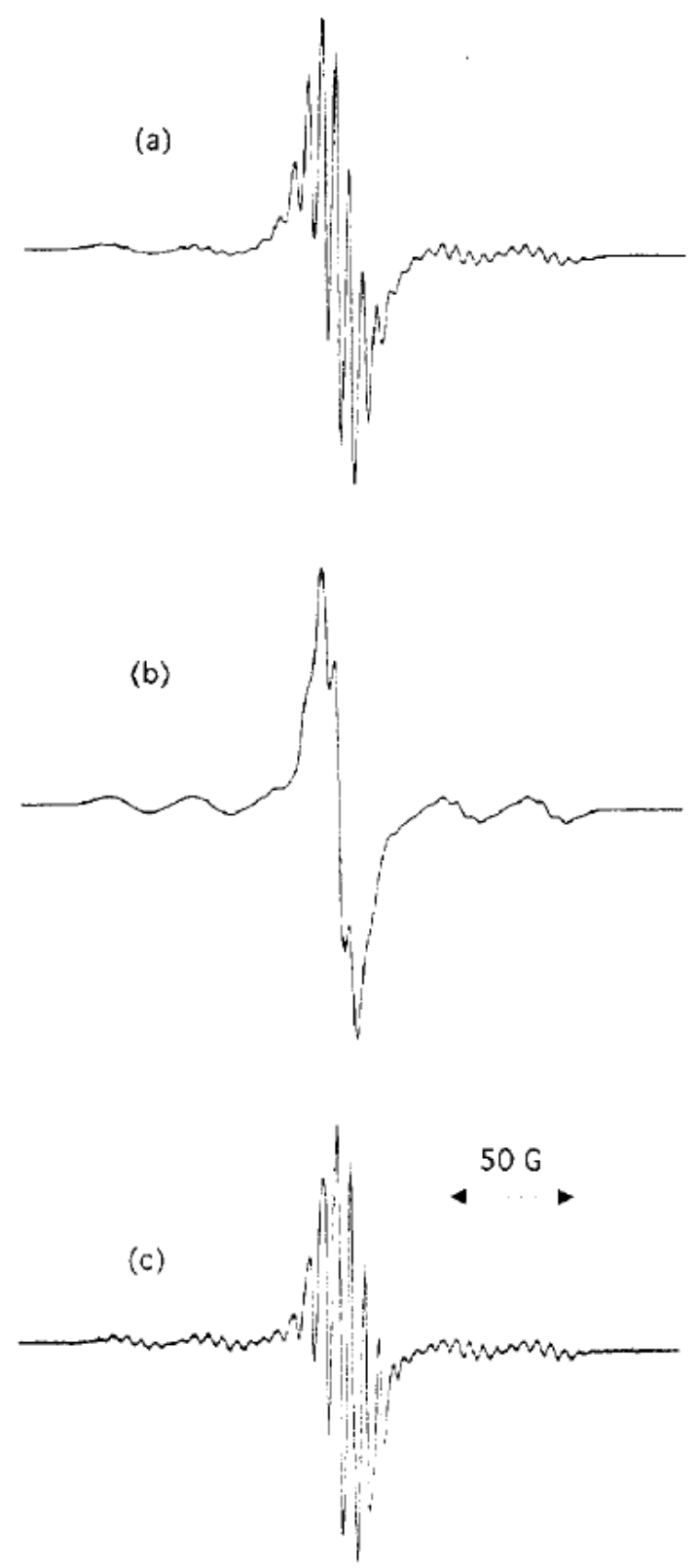

Fig. 1. EPR spectra for (a) $\mathrm{CpMo}\left(\mathrm{CH}_{3}\right)_{2}\left(\eta^{4}-\mathrm{C}_{4} \mathrm{H}_{6}\right)$, 1, at $-80^{\circ} \mathrm{C}$ in toluene. (b) $\mathrm{CpMo}\left(\mathrm{CD}_{3}\right)_{2}\left(\eta^{4}-\right.$ $\left.\mathrm{C}_{4} \mathrm{H}_{6}\right), \mathbf{1}-\mathrm{d}^{6}$, at $-113^{\circ} \mathrm{C}$ in $\mathrm{Et}_{2} \mathrm{O}$. (c) $\mathrm{CpMoCl}\left(\mathrm{CH}_{3}\right)\left(\eta^{4}-\mathrm{C}_{4} \mathrm{H}_{6}\right)$, 2, at room temperature in toluene. 

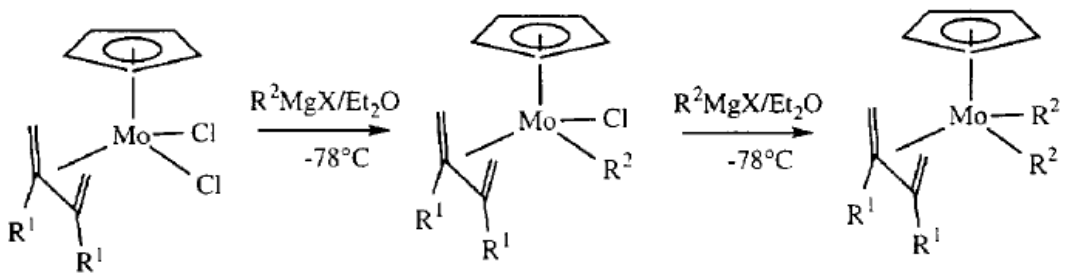

\begin{tabular}{ll|l}
$\mathrm{R}^{1}$ & $\mathrm{R}^{2}$ & \\
\hline $\mathrm{H}$ & $\mathrm{Me}$ & $\mathbf{2}$
\end{tabular}

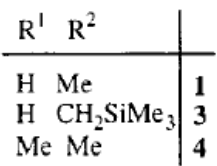

\section{Scheme 1}

Compounds 1-4 are stable under an inert atmosphere at room temperature and in the dark. Less than $50 \%$ decomposition is observed over $22 \mathrm{~h}$ upon warming compound $\mathbf{1}$ to $70^{\circ} \mathrm{C}$ in toluene in the dark as judged by EPR spectroscopy. The unexpected thermal stability of this material, especially when compared with the ease of bond homolysis in the isoelectronic compound $\mathrm{CpMo}\left(\mathrm{CH}_{3}\right)_{2}\left(\mathrm{PMe}_{3}\right)_{2}$ [13], does not have an obvious explanation. A faster decomposition process, resulting in the precipitation of a black intractable material, occurs at room temperature upon exposure to light. Pentane solutions of compound $\mathbf{2}$ exposed to the laboratory light, on the other hand, led to the formation of crystals of compound $[\mathrm{CpMo}(\mu-$ $\left.\mathrm{Cl})\left(\eta^{4}-\mathrm{C}_{4} \mathrm{H}_{6}\right)\right]_{2}[5]$, upon standing at room temperature over $>1$ week, presumably by Mo(III)$\mathrm{CH}_{3}$ bond homolysis. The susceptibility of $\mathrm{Mo}(\mathrm{III})$-alkyl compounds toward Mo-R bond homolysis as a function of the ancillary ligands will be a topic of further investigations in our laboratory.

Preliminary studies show that compound $\mathbf{1}$ is quite unreactive toward Lewis bases. The interaction with either $\mathrm{CO}(1 \mathrm{~atm})$ or $\mathrm{PMe}_{3}$ over 2 weeks at room temperature, or with $\mathrm{PEt}_{3}$ over $24 \mathrm{~h}$ at $65^{\circ} \mathrm{C}$ in THF gave only a slight decrease of EPR intensity for the starting material and no evidence for the formation of new soluble products by EPR, NMR or IR spectroscopy. This is again quite surprising, since the $\mathrm{CO}$ insertion process into metal-alkyl bonds is generally thought to be a thermodynamically favorable and facile process for 17-electron compounds $[14,15]$. Also, the lack of reactivity with $\mathrm{PR}_{3}(\mathrm{R}=\mathrm{Me}, \mathrm{Et})$ contrasts with the easy decomposition of $\mathrm{CpMo}\left(\mathrm{CH}_{3}\right)_{2}\left(\mathrm{PMe}_{3}\right)_{2}$, leading to $\mathrm{CpMo}\left(\mathrm{CH}_{3}\right)\left(\mathrm{PMe}_{3}\right)_{3}$ in the presence of $\mathrm{PMe}_{3}$ [13].

The addition of protons, on the other hand, results in a facile heterolytic cleavage of the Mo- $\mathrm{CH}_{3}$ bond: reaction with $\mathrm{CF}_{3} \mathrm{CO}_{2} \mathrm{D}$ leads to the evolution of $\mathrm{CH}_{3} \mathrm{D}$. These combined reactivity essays indicate that the complex, in spite of its electronically unsaturated configuration, is rather electron-rich. The electron-richness of this system is confirmed by 
cyclic voltammetric studies, which show a reversible one-electron reduction process at quite negative potentials $\left(E_{1 / 2}=-2.09 \mathrm{~V}\right.$ for $\mathbf{1},-1.97 \mathrm{~V}$ for $\mathbf{3}$, and $-2.14 \mathrm{~V}$ for $\mathbf{4}$, all versus. the ferrocene standard in THF solution), namely ca. $1 \mathrm{~V}$ more negative with respect of the same reduction process for $\mathrm{CpMoCl}_{2}\left(\eta^{4}-\mathrm{C}_{4} \mathrm{H}_{6}\right)$ [4]. The mixed complex 2 correspondingly shows a reversible reduction process at $E_{1 / 2}=-1.62 \mathrm{~V}$, midway between those of $\mathbf{1}$ and the dichloride precursor. All these compounds also show irreversible oxidation waves. Additional reactivity studies with Lewis-acidic reagents and with oxidizing agents are under investigation and will be the subject of a future full report.

\section{Acknowledgments}

This work was supported by the Conseil Régional de Bourgogne and by the CNRS (Programme Catalyse pour l'Industrie et l'Environnement). E. L. G. thanks the MENRT for a doctoral fellowship.

\section{References and Notes}

1 To a suspension of $\mathrm{CpMoCl}_{2}\left(\eta^{4}-\mathrm{C}_{4} \mathrm{H}_{6}\right)(534 \mathrm{mg}, 1.86 \mathrm{mmol})$ in $30 \mathrm{~cm}^{3}$ of $\mathrm{Et}_{2} \mathrm{O}$ at $-78^{\circ} \mathrm{C}$ was added $1.4 \mathrm{~cm}^{3}$ of $\mathrm{MeMgBr}$ in $\mathrm{Et}_{2} \mathrm{O}(3.0 \mathrm{M}, 4.1 \mathrm{mmol})$. The resulting mixture was stirred while being allowed to warm up slowly (ca. $2 \mathrm{~h}$ ) to room temperature. During this time the brown suspension turned green. The solvent was removed under reduced pressure and the residue was extracted with pentane, followed by filtration through Celite. The solution was evaporated under reduced pressure to dryness, yielding compound $\mathbf{1}$ as a dark-green powder (232 mg, 51\% yield). Analysis: Calcd for $\mathrm{C}_{11} \mathrm{H}_{17} \mathrm{Mo}$ : C, 53.88; H, 6.99\%. Found: C, 53.73; $\mathrm{H}, 7.34$. EPR (toluene, $-80^{\circ} \mathrm{C}$ ): undecet with Mo satellites; $g=2.012 ; a_{\mathrm{Mo}}=33.3 \mathrm{G} ; a_{\mathrm{H}}=$ 5.5 G. Compound $1-\mathrm{d}^{6}$ was obtained by an identical procedure using a $1.0 \mathrm{M} \mathrm{Et}_{2} \mathrm{O}$ solution of $\mathrm{CD}_{3} \mathrm{MgI}$. EPR spectrum $\left(\mathrm{Et}_{2} \mathrm{O},-113^{\circ} \mathrm{C}\right)$ : quintet with Mo satellites; $g=2.012 ; a_{\mathrm{Mo}}=33.0$ $\mathrm{G} ; a_{\mathrm{H}}=5.5 \mathrm{G}$.

2 By a procedure analogous to that described above (synthesis of $\mathbf{1}$ ) but using only 1.1 equiv of the Grignard reagent and THF as solvent, led to the isolation of a green powder of compound 2 (69 \%). Analysis: Calcd for $\mathrm{C}_{10} \mathrm{H}_{14} \mathrm{ClMo}$ : C, 45.22; H, $5.31 \%$. Found: C, 45.22; H, 5.63. EPR (toluene, room temperature): octet with Mo satellites; $g=2.012 ; a_{\mathrm{Mo}}=$ $32.9 \mathrm{G} ; a_{\mathrm{H}}=5.7 \mathrm{G}$. 
3 Compound 3: $g=2.009 ; a_{\mathrm{Mo}}=36.5 \mathrm{G} ; a_{\mathrm{H}}=5.3 \mathrm{G}$ in $\mathrm{Et}_{2} \mathrm{O}$ at room temperature. Compound 4: $g=2.013 ; a_{\mathrm{Mo}}=33.3 \mathrm{G} ; a_{\mathrm{H}}=5.8 \mathrm{G}$ in pentane at $168 \mathrm{~K}$; anal.: calcd for $\mathrm{C}_{13} \mathrm{H}_{21} \mathrm{Mo}: \mathrm{C}$, $57.14 ; \mathrm{H}, 7.75 \%$. Found: C, 56.99; H, 7.56. The identity of compound 4 is also confirmed by an X-ray structural determination, which will be reported in a subsequent full paper.

[1] B. S. Buyuktas, M. M. Olmstead and P. P. Power, Chem. Commun. (1998) 1689-1690.

[2] W. Hübel and R. Merényi, J. Organomet. Chem. 2 (1964) 213-221.

[3] R. Poli, J. Coord. Chem. B 29 (1993) 121-173.

[4] J. L. Davidson, K. Davidson, W. E. Lindsell, N. W. Murrall and A. J. Welch, J. Chem. Soc., Dalton Trans. (1986) 1677-1688.

[5] L.-S. Wang, J. C. Fettinger and R. Poli, J. Am. Chem. Soc. 119 (1997) 4453-4464.

[6] P. W. Jolly, C. Krüger, C. C. Romão and M. J. Romão, Organometallics 3 (1984) 936937.

[7] R. Poli and L.-S. Wang, Polyhedron 17 (1998) 3689-3700.

[8] B. Heyn, Z. Chem. 8 (1968) 426.

[9] B. Sarry and P. Velling, Z. anorg. allg. Chem. 500 (1983) 199-209.

[10] W. Mowat, A. Shortland, G. Yagupsky, N. J. Hill, M. Yagupsky and G. Wilkinson, J. Chem. Soc., Dalton Trans. (1972) 533-542.

[11] M. H. Chisholm and I. P. Rothwell, J. Am. Chem. Soc. 102 (1980) 5950-5952.

[12] M. H. Chisholm, Acc. Chem. Res. 23 (1990) 419-425.

[13] R. Poli, S. T. Krueger, F. Abugideiri, B. S. Haggerty and A. L. Rheingold, Organometallics 10 (1991) 3041-3046.

[14] R. H. Magnuson, R. Meirowitz, S. Zulu and W. P. Giering, J. Am. Chem. Soc. 104 (1982) 5790-5791.

[15] W. C. Trogler, in Organometallic Radical Processes (W. C. Trogler, ed.), Vol. 22, p. 306337. Elsevier, Amsterdam, 1990. 